\title{
Rewarding Employees through Specific Wage Scales - Analysing the Remuneration Scheme Using Fixed Wage Elements in a Selected Company
}

\author{
Dana Lakronová1,* \\ ${ }^{1}$ Institute of Technology and Business, Faculty of Corporate Strategy, Okružní 517/10, 37001 České Budějovice, Czech Republic
}

\begin{abstract}
The presented article examines rewarding employees on different wage scales by exploring a remuneration scheme using fixed wage elements of a specific enterprise. The submitted study evaluates the remuneration scheme in Č́eské Dráhy Plc. and its influence on the company. The achieved results of formulated hypotheses will be analysed through a structured interview and observation methods.
\end{abstract}

Keywords: wage scheme; remuneration; wage scale; fixed elements; work evaluation

\section{Introduction}

The human factor constitutes the principal part of the production process. Employees must therefore be properly motivated to perform at their best. Adequate remuneration of personnel is a crucial aspect throughout companies, constituting one of the critical elements of motivation. The remuneration scheme is always tailored to the requirements of a particular company to satisfy the needs not only of their employees, but also the company as a whole.

Specific remuneration schemes provide workers with financial or non-financial reward for their contribution to the company, also focusing on strengthening their motivation and inspiring loyalty. Enterprises may choose from various methods and factors of remuneration. The wage scheme must be effective, depending on a variety of factors including adequate wage structures. Creation of a high quality and elaborate remuneration system should thereby be the major focus of the department of human resources. The human factor encompasses a unique investment capital requiring effective management. Nowadays, companies must strive for winning the loyalty of their workers, as quality and wellpaid employees ensure competitiveness of the enterprise. In my research, I focused on České dráhy Plc. The company was involved in large number of railway accidents that had happened during the summer. In the submitted article, I aim to inspect wages of selected posts in the company. I chose one position and compared it with other transport organizations to explore the impact of workers' salaries on railway transport safety.

The article is divided into a theoretical and application part. The theoretical-methodological part involves professional literature expounding upon terms concerning wage schemes, such as wages, wage scales and remuneration system. It further refers to methods used for gathering the material in the application part. The application part deals with describing a specific enterprise, its wage scheme and impact on the functioning and prosperity of the enterprise, including its influence on the staff motivation.

Hypothesis 1: Remuneration scheme is highly impactful on the staff performance.

Hypothesis 2: The tariff remuneration scheme scales with personnel's increased qualification and their bonuses.

\section{Literary research}

The topic of employee remuneration has widely been discussed in professional literature, including national and foreign studies. This article focuses on defining the specific terminology, referring to basic terms such as employee remuneration, wages, wage elements etc.

The highly instrumental publications involve "Motivating and remunerating employees" [1] or older works of Nakonečný [2], who clearly explains the importance of remuneration as an efficient motivational tool for employees to enhance their performance. Financial reward constitutes a key factor of a long-term working relationship, allowing employers to stimulate their staff to higher performance by giving bonuses. However, it is presumed that the harder and demanding the work is, the higher the requirements for skills are and the higher the performance of the workers should be. Enterprises should also try to preserve wage justice, where separate activities are classified according to their difficulty. Employees will thereby better understand the difference between their wages and salaries of their colleagues who perform more or less demanding work [3].

\footnotetext{
* Corresponding author: $18361 @$ mail.vstecb.cz
} 
Wages are, however, only one aspect contributing to work motivation and do not necessarily have to be the crucial one. Armstrong [4] argues that money is a positive stimulus not only because of a sheer need for it, but also implying explicit recognition of employees. The reward must clearly reflect the effort or degree of worker's responsibility. This is a different view on the issue of remuneration, Armstrong [5]. Wöhe and Kislingerová [3] suggest that the business economy determines employees' wages according to their working performance. Wages as a way of remuneration of one production factor accounts for a business quantity affecting incurred costs. Workers must be remunerated under employment contracts independent from the current situation of the enterprise. Urban [6] in his publications "Management and Leadership Psychology" and "Corporate Human Resource Management: Dimension of Human Resource Management" [7] broadens the knowledge of human resource management and business management. Mukherjee [8] in his work "Principles of Management and Organizational Behaviour" outlines principles of human resource management and organizational behaviour of employers.

Of significance might also be an article from scientific databases by Wakabayashi [9] "Fixed Salary or Incentive Contract? The Effect of Stickiness of Compensation Contracts". The study explores contractual theory, collective agreements and fixed wage elements. Bajzikova [10] in her article "The Minimum Wage in Compensation Systems in EU and the Slovak Republic" analyses remuneration schemes, perks and drawbacks of minimum wages, assessing their role in remuneration systems. The study further concerns remuneration in terms of bonuses and other job perks depending on workers' performance. Yoon [11] in his book "Mechanisms underlying creative performance: Employee perceptions of intrinsic and extrinsic rewards for creativity" describes the principle of viewing workers on the grounds of intrinsic and extrinsic bonuses for their creativity and performance. Bi-xi [12] in his article "Wage system innovation in small and middle manufacture enterprise" focuses not only on small and medium-sized manufacturers, but also suggests convenient methods of improving remuneration schemes tailored to various manufacturing companies. Hanes [13] in his study "The rise and fall of the sliding scale, or why wages are no longer indexed to product prices" outlines a gradual decline of sliding scales and their practical experience.

\section{Methodology}

The following chapter briefly describes the enterprise concerned, systematically exploring methods of collecting the relevant data for the research in question.

The first part expounds upon basic terms relating to employee remuneration, specifically focusing on expressions such as wages, wage scale, and different types of remuneration, also comparing opinions of various experts.

The practical part fully describes the selected company, provides basic information and analyses the particular system of the company. It further deals with the decisive criteria for remunerating individual jobs, the stability and employees' motivation including corporate costs and expenses. This part also compares the remuneration of engine drivers in two different companies.

The employed approaches involve observation methods and structured interview with the head of the human resource department (whose job content is: a manager of transport and logistics and deputy chairman of railwaymen trade union) comprising five questions. The interview targets specific criteria of remunerating workers, the remuneration scheme in the whole company, comparison of the contractual salary with the tariff salary, the impact on the performance and behaviour of employees and their motivation.

The final part of this article discusses the findings, either confirming or rejecting the formulated hypotheses. The conclusion summarizes all recorded findings as well as it suggests appropriate measures for overhauling the particular wage scheme. For the aforementioned purposes, I chose two positions to analyse in terms of remuneration, involving an engine driver and the head accountant. I will thoroughly discuss this issue in my diploma thesis.

For my research, I chose a Public limited company České dráhy established on 1st January 2003 under Act 77/2002 $\mathrm{Sb}$. as a successor legal subject of the original national organization České dráhy. The company tightly integrates passenger transport and haulage with rail transport routes on the regional and national railways owned by the state.

Upon transforming České dráhy organization, three successor establishments emerged: Public limited company České dráhy, providing services in passenger transport and haulage and ensuring serviceability of the rail transport route, Railway Administration National Organization, disposing of the state property, making the transport route available to railway carriers and ensuring modernization of the transportation infrastructure, and the Railway Inspection as an organizational unit for resolving extraordinary events.

České dráhy constitutes a railway enterprise ranking amongst the biggest employers in Czechia. The group of companies České dráhy involves České dráhy Plc. as a passenger railway transport undertaking and ČD Cargo Plc. as a haulier. Organizational units of ČD (České dráhy) comprise the managing directorate, detached branches of the business, organizational units and executive units. $\breve{C} D$ includes several subsidiaries such as:

- ČD Travel Ltd.,

- Dopravní vzdělávací institut Plc.,

- Výzkumný Ústav Železniční Plc.,

- $\quad \check{C} D-T e l e m a t i k a ~ P l c .$, 
- ČD-Informační systémy Plc.,

- $\quad \check{C} D$ Reality Plc.,

- ČD Restaurant, Plc.,

- RailReal Plc.,

- Žižkov Station Development Plc.,

- Smíchov Station Development Plc.,

- DPOV Plc.

\section{Results}

The following part considers all results achieved from observing and interviewing.

\section{1 ČD Remuneration code for ČD workers}

All employees, including ČD workers, are entitled to wages for the performed work, involving tariff wages and other related wages components provided according to the remuneration code. In compliance with the code, employees are further entitled to compensation for the on-call duty and wage reimbursement. $\breve{C}$ C Company presents a wise choice for workers due to its coherent monetary policy. Basic wage and related wages components paid by the enterprise give security and social stability to our employees. České dráhy ranks third on the Best Employer of 2020 Chart including companies exceeding 5,000 employees.

The ČD remuneration scheme is based upon hourly pay. The wages reflect the monthly tariff or the wages negotiated in the contract, complying with working hours or calculated as a product of the hourly tariff of the declared tariff rate and hours worked. Most workers of the company are remunerated under specific tariff rates. Senior managers are paid pursuant to the contractual salary.

České dráhy Plc. collaborated with the Ministry of Labour and Social Affairs of the Czech Republic on the list of jobs and related tariff rates. The tariff rates are classified according to the complexity, difficulty and responsibility, labour intensity and significance of the job performed for $\breve{C} D$. It is imperative to realize that particular characteristics may not allow for all the possibilities and at times they just describe the performed work in general.

Employees are classified into specific tariff rates within one employment according to the qualification difficulty of the predominantly performed work. If certain requirements for specific tariff rates are identical, the decisive factor for ranking into a higher tariff rate is fulfilling the requirement that separates texts of higher rates from the lower ones. In certain positions, the amount of wages is set just according to an individual agreement. The application of the tariff rates and contractual wages in separate organizational units is governed by prescribed systematization upon meeting particular pre-conditions. The employees are remunerated under The Employee Remuneration Code of ČD suggested in Table 1. The terms relating to the educational background are explained in the list below the table.

Table 1. Tariff rates of České dráhy Plc.

\begin{tabular}{|c|c|l|}
\hline Tariff rate & Monthly tariff & \multicolumn{1}{|c|}{$\begin{array}{c}\text { Indicative qualification prerequisites (educational } \\
\text { background + standing) }\end{array}$} \\
\hline 1 & 14,600 & A, B, C (+ apprenticeship or training) \\
\hline 2 & 14,980 & A, B, C, D (apprenticeship or training) \\
\hline 3 & 16,420 & D, E \\
\hline 4 & 18,250 & E, J, H \\
\hline 5 & 19,990 & J + 1 year of standing, $\mathrm{H}, \mathrm{K}$ \\
\hline 6 & 21,900 & $\mathrm{H}+2$ years of standing, $\mathrm{K}+1$ year of standing, M, L \\
\hline 7 & 23,700 & $\begin{array}{l}\mathrm{H}+3 \text { years of standing, } \mathrm{K}+2 \text { years of standing, } \mathrm{M}+1 \text { year } \\
\text { of standing, } \mathrm{L}+1 \text { year of standing }\end{array}$ \\
\hline 8 & 25,410 & $\begin{array}{l}\mathrm{H}+4 \text { years of standing, } \mathrm{K}+3 \text { years of standing, } \mathrm{M}+2 \text { years } \\
\text { of standing, } \mathrm{L}+2 \text { years of standing }\end{array}$ \\
\hline 9 & 27,220 & $\begin{array}{l}\text { M }+3 \text { years of standing, } \mathrm{L}+3 \text { years of standing, } \mathrm{N}+1 \text { year of } \\
\text { standing, } \mathrm{R}\end{array}$ \\
\hline 10 & 29,000 & $\begin{array}{l}\text { M + 4 years of standing, } \mathrm{L}+4 \text { years of standing, } \mathrm{N}+2 \text { years } \\
\text { of standing, } \mathrm{R}+1 \text { year of standing }\end{array}$ \\
\hline 11 & 30,650 & $\begin{array}{l}\text { M + 6 years of standing, } \mathrm{L}+6 \text { years of standing, } \mathrm{N}+2 \text { years } \\
\text { of standing, } \mathrm{R}+2 \text { years of standing, } \mathrm{T}+1 \text { year of standing }\end{array}$ \\
\hline
\end{tabular}




\begin{tabular}{|l|l|l|}
\hline 12 & 32,560 & $\begin{array}{l}\mathrm{N}+4 \text { years of standing, } \mathrm{R}+3 \text { years of standing, } \mathrm{T}+1 \text { year of } \\
\text { standing }\end{array}$ \\
\hline 13 & 33,380 & $\mathrm{R}+4$ years of standing, $\mathrm{T}+3$ years of standing \\
\hline 14 & 35,580 & $\mathrm{R}+6$ years of standing, $\mathrm{T}+5$ years of standing \\
\hline 15 & 39,830 & $\begin{array}{l}\mathrm{R}+8 \text { years of standing, } \mathrm{T}+7 \text { years of standing } \mathrm{V}+5 \text { years of } \\
\text { standing }\end{array}$ \\
\hline 16 & 43,950 & $\mathrm{~T}+8$ years of standing, $\mathrm{V}+7$ years of standing \\
\hline
\end{tabular}

Source: Author based on the data of Collective agreement of $\check{C} D 2020$.

\section{The list of qualification prerequisites and educational background}
A Without education (incomplete primary education)
B Without education (completed primary education)
C The basic education (one-year and two-year vocational school)
D Lower secondary education (three-year preparation at a secondary vocational school)
E Lower secondary vocational education (vocational education schemes, vocational schools)
J Secondary or secondary vocational education without the general secondary education exam or vocational certificate
$H \quad$ Secondary vocational education with the vocational certificate (a graduate of non-graduation educational schemes)
K Completed secondary education
M Completed secondary vocational education with the general secondary education exam (without apprenticeship)
L Completed secondary vocational education with apprenticeship and general secondary education exam
$N \quad$ College education (colleges, conservatories, post-secondary specialized education)
$R \quad$ Bachelor education (University education completed by bachelors exams)
T Master education (master, engineer and medical schemes)
V Doctoral education (doctoral study programme, postgraduate studies, scientific education)

Discussing employee remuneration also involves negotiating between the employer and trade unions on the budget of wage costs.

The negotiated wages involve a so-called fixed wages component (guaranteed wages component), which the employee may always take for granted. It equals no less than two thirds of the overall wages. The rest underlies performing other pre-negotiated conditions evaluated by the senior worker. Remuneration according to tariff rates provides workers with financial security. All employees, paid either under a specific tariff rate, or pursuant to the contractual salary, are motivated to higher work performance by bonuses added to the basic wages. In the event that an employee fails to perform an employee's duty, the bonuses are reduced. In this way, performance bonuses are considered as motivational tools. Most operating employees are also liable to indemnify the employer if the damage is caused by employees' work performance. In such a case, the employee is liable to indemnity not exceeding three monthly salaries.

With an exception of specific cases where contractual wages apply, all ČD employees are subject to tariff wages. It is thereby presumed that all professions share the same base remuneration. Certain specifics may be found in so-called operating professions, e.g. administrative and operating positions. It generally applies that all employees' bonuses provided by our company are predominantly governed by The Labour Code. To a certain extent, the amount of bonuses is subject to negotiation between the employer and trade unions. From my point of view, these bonuses may then be considered as a motivational tool. Educational background is imperative for assigning the worker a particular job and the respective tariff rate. Above all, the educational background is highly impactful on the bonuses determined by the length of service. In particular, higher education provides the employee with two extra years of standing.

\section{Engine driver - operating position}

- The job involves expertise in controlling, service and maintenance of driving vehicles of passenger transport trains, higher quality trains and international trains within railway services.

- The position falls into 10th, 11th and 12th tariff rate according to the service classification regarding respective train categories. The engine driver is further entitled to negotiate on a contractual salary. In such a case the engine 
driver, besides other things, controls, services and maintains driving vehicles of trains. The engine driver shall also submit a certificate of proving his/her language knowledge and official authorization for a position of an engine driver on international railway lines.

- Time allocation amounts to 36 hours a week.

- The main bonuses to wages involve personal evaluation, bonuses determined by the length of service, bonuses for working overnight, bonuses for working on Saturday and Sunday, bonuses for working on holiday and bonuses for the work release programme.

- This position includes very specific wage bonuses:

- bonuses for the on-call duty

- $\quad$ bonuses for avoiding profit leaks

- compensation for extraordinary events, remuneration when working under unfavourable weather conditions, including the consequences

- remuneration for taking part in a training course, examination, studying on the job and retraining

- Operating employees are entitled to "compensation for separate shifts" - a profession where a worker spends working hours outside his/her domicile, including without limitations employees in transport, e.g. a chief conductor. He/she is paid $60 \%$ of his/her hourly wage up to 2 hours, of which the amount increases to $75 \%$ when the time of the separate shift exceeds 2 hours.

\section{Head accountant - administrative position}

- The job involves specialized and professional administration of employees' accounts, providing and inspecting annual and monthly financial statements including tax checkouts. The post further includes thorough knowledge of the payroll software and legislation pertaining to wage accounting and providing checkout as required by the competent administrative bodies.

- The position falls into 12 th tariff rate with the time allocation 40 hours a week.

- The position is exclusively administrative; workers are not entitled to issue a statement on working overtime.

- $\quad$ Administrative workers are entitled to take the accrued days off.

- The salary of the administrative worker comprises: the tariff, bonuses determined by the length of service, personal evaluation or reimbursement of traveling costs.

- The worker is entitled to the reimbursement of travelling costs if he/she is commissioned to work outside his/her domicile, e.g. he/she is appointed as a substitute for a sick employee.

\subsection{Comparing wages of engine drivers in České dráhy Plc. and RegioJet}

Specific requirements of both companies involve an evaluation of worker's state of health pursuant to Regulation No. 101/95 Sb. MD being without criminal records and responsibility. České dráhy offers training course if the candidate does not have an engine driver license. The candidate must also have his/her secondary education completed and submit his/her vocational certificate of transport or related education. RegioJet requires competence to drive a railway vehicle and expertise in technical areas of railway transport.

Table 2. Comparing salaries and perks

\begin{tabular}{|l|l|l|}
\hline & České dráhy & RegioJet \\
\hline Net wages & $31,000 \mathrm{CZK}$ & $34,000 \mathrm{CZK}$ \\
\hline Bonus & $13,000 \mathrm{CZK}$ & $12,000 \mathrm{CZK}$ \\
\hline Meal vouchers & $110 \mathrm{CZK}$ & No \\
\hline Employee discount on the train ride & Yes & Yes \\
\hline Days off & 5 weeks & 5 weeks \\
\hline
\end{tabular}

Source: Author.

The suggested comparison shows that both companies offer a large number of job perks. České dráhy has the biggest competitive advantage in its long-established tradition and corporate stability. On the other hand, RegioJet suffers from being a complete novice on the market. Although the enterprise has recently been trying to entice potential candidates by pushing up wages of engine drivers, the real-life situation might be quite different. 


\section{Discussion}

I have reasonable cause to believe that railroad accidents predominantly involve fault of a human factor - either of a railway employee, or drivers of road vehicles. All the same, railway transport is considered one of the safest ways of transportation. Railway lines are secured by various safety and communication devices, scaling with the traffic volume on the respective lines. Available funds allocated to the greater safety and their potential profit-making are imperative for preventing tragic accidents. The level of railway safety is always thoroughly examined when it comes to railroad crashes, although we cannot simply say that safety factors are involved in all railway accidents. Even the lowest degree of safety makes the railway traffic completely secure. It leads us to the question of the human factors involved in the process of railway traffic control. As an example, I can give a railway line controlled only by telephone communication, and a line secured by automated systems using IT technologies and modern safety devices.

There has been a profound lack of certified engine drivers on the market, affecting all carriers - České dráhy, RegioJet and Leo Express. The companies try to maintain these driving specialists by a pay rise. In the event of ČD, the situation is not that critical, as the enterprise does not face a rapid labour turnover. The organization also benefits from a long-term elaborate and effective preparatory programme for trainees. The training of new engine drivers is financially and time consuming, with the duration of no less than 9 months. The course, however, usually lasts longer, since not all carriers devote the same amount of time to the training. Other organizations try to attract new workers on a pay increase. RegioJet has raised its basic wages by 12 - 14\%, whereas Leo Express has pushed up its salaries by $5 \%$.

\section{Conclusion}

In the article, I analysed and evaluated the current remuneration scheme in České dráhy Plc. assessed its effectiveness and the impact on the stability and security of the company, coming up with constructive suggestions within the aforementioned scheme.

In the theoretical part, I focused on a general description of the remuneration scheme, bonuses for the performed work and overall elaboration of the system. In the practical part, I introduced České dráhy Plc. exploring its remuneration system and testing formulated hypotheses. I also found an answer to the issue of rail transport safety, considering recent accidents and their possible link to the company remuneration policy. As to suggested remedial measures, the corporation itself has involved in its employment contracts for operating employees that the working position occupied in the company may not be held in any other competing company at the same time. These measures have not been imposed until recently. České dráhy Plc. ranks third amongst the best employers in the Czech Republic. Its employees are thereby very well looked after and are offered jobs and excellent salary packages in a stable environment, the information which was found out by inspecting the collective agreement. Even though the enterprise has firmly set its tariff rates, certain positions can negotiate a contractual salary outside the fixed tariff rates.

The chamber of deputies is currently considering a bill to amend the Railway Act, which stipulates uniform laws of the railway transport throughout the European Union, on the national level introducing the monitoring of the prescribed time spent by driving a railway vehicle on a national or regional line. The amendment aims at ensuring safety of the railway transport on the EU market. The modification of the prescribed time spent by driving railway vehicles on a national or regional line enables better controlling, sticking to the rules governing the shift length and the time spent by driving the railway vehicle in international transportation. General rules and regulations governing the operating and technical linkage between the national and regional lines and lines of other members of the EU were imposed.

Based upon the employed methods, the formulated hypotheses were successfully confirmed.

\section{References}

1. J. Urban. Motivace a odměňování pracovníků. Praha: Grada. ISBN 978-80-271-0227-3 (2017)

2. M. Nakonečný. Motivace pracovního jednání a jeho ř́zení. Praha: Management Press (1992)

3. G. A. Wöhe, E. Kislingerová. Úvod do podnikového hospodářství. Praha: C.H. Beck, ISBN 978-80-7179-897-2 (2007)

4. M. Armstrong. Řizení lidských zdroju: nejnovějši trendy a postupy. Praha: Grada, ISBN 978-80-247-1407-3 (2007)

5. M. Armstrong. Odměňování pracovníků. Praha: Grada, Expert (Grada). ISBN 978-80-247-2890-2 (2009)

6. J. Urban. Psychologie ř́zení a vedení. Praha: Ústav práva a právní vědy. ISBN 978-80-87974-15-5 (2017)

7. J. Urban. Řizení lidí v organizaci: Personální rozměr managementu. Praha: Wolters Kluwer (2013)

8. K. Mukjerjee. Principles of Management and Organizational Behaviour. New Delhi: Tata McGraw-Hill Education Private Limited (2009) 
9. T. Wakabayashi. Fixed salary or incentive contract? The effect of stickiness of compensation contracts. Asia-Pacific Journal of Accounting and Economics. (2019)

10. L. Bajzikova. The minimum wage in compensation systems in EU and the Slovak Republic. Proceedings of the 31 st International Business Information Management Association Conference, IBIMA 2018: Innovation Management and Education Excellence through Vision 2020. 1550 (2018)

11. H. J. Yoon, S. Y. Sung, J. N. Choi. Mechanisms underlying creative performance: Employee perceptions of intrinsic and extrinsic rewards for creativity. Social Behavior and Personality. 43(7), 1161-1180 (2015)

12. Z. Bi-Xi, X. Xiang-Tian. Wage system innovation in small and middle manufacture enterprise. 2007 IEEE International Conference on Control and Automation, ICCA. 752 (2007)

13. C. Hanes. The rise and fall of the sliding scale, or why wages are no longer indexed to product prices", Explorations in Economic History. 47(1), pp. 49-67 (2010)

14. České dráhy. Collaborative Agreement (2020) 